\title{
Neodusmetia sangwani (Subba Rao) (Hymenoptera: Encyrtidae) to control Antonina graminis (Maskell) (Hemiptera: Pseudococcidae) in pastures in Brazil: a revision
}

\author{
Neodusmetia sangwani (Subba Rao) (Hymenoptera: Encyrtidae) para o \\ controle de Antonina graminis (Maskell) (Hemiptera: Pseudococcidae) em \\ pastagens no Brasil: uma revisão
}

\author{
Antonio Batista Filho ${ }^{*}$, Valmir Costa ${ }^{1}$, Harumi Hojo ${ }^{1}$ \\ | | | | | | | | | | | | | | | | | | | | | | | | | | | | | | | | | | | | | | | | | | | | | | | | | | | | | | | | | | | | | | | | | | | | | | | | | | | | | | | | | | | | | | | | | | | | | | | | | | | | | | | | | | | | | | | | | | | | | | | | | | | | | | | | | | | | | | | | | | | | | | | | | | | | | | | | | | | | | | | | | | | | | | | | | | | | | | | | | | | | | | | | | | | | | | | | | | |
}

\begin{abstract}
The use of the parasitoid Neodusmetia sangwani to control the Rhodes grass mealybug Antonina graminis is one of the best examples of classical biological control in the world. The situation could not be different in Brazil, where the pest has also been introduced, and kept under control after the release of its natural enemy. In this review, it is united information with respect to the successful use of a natural enemy in this country. Notes about the description and biology of the insects involved and rearing and release procedures of the parasitoid for the Rhodes grass mealybug control in Brazil will also be presented.
\end{abstract}

KEYWORDS: classical biological control; natural enemy; parasitoid; Rhodes grass scale.
RESUMO: O uso do parasitoide Neodusmetia sangwani para controlar a cochonilha-das-pastagens Antonina graminis é um dos melhores exemplos de controle biológico clássico no mundo. A situação não poderia ser diferente no Brasil, onde a praga foi introduzida e mantida sob controle após a liberação de seu inimigo natural. Nessa revisão são reunidas informaçôes sobre o bem-sucedido uso de um inimigo natural nesse país. Serão apresentadas também notas sobre a descrição e biologia dos insetos envolvidos e procedimentos de multiplicação e liberaçáo do parasitoide para o controle dessa cochonilha no Brasil.

PALAVRAS-CHAVE: controle biológico clássico; inimigo natural; parasitoide; cochonilha-das-pastagens. 


\section{INTRODUCTION}

The Rhodes grass mealybug Antonina graminis (Maskell) (Hemiptera: Pseudococcidae) is an insect extremely damaging to diverse species of grasses utilized in the formation of pastures. It is not known exactly when this insect arrived in Brazil, but it is estimated to have been about 1940 or in the late 1930s, when pastures were observed with damage by this insect on Angola grass in the municipality of Irará, state of Bahia (WILLIAMS; SCHUSTER, 1970). Since then, this mealybug has been encountered on about one hundred species of grasses (FONSECA, 1967; WILLIAMS; SCHUSTER, 1970). The introduction of the parasitoid Neodusmetia sangwani (Subba Rao) (Hymenoptera: Encyrtidae) into the country occurred in October 1967, with authorization of the Ministry of Agriculture, and the initial multiplication was responsibility of the Instituto de Pesquisas Agropecuárias do Leste (IPEAL), Cruz das Almas, BA (currently EMBRAPA Mandioca e Fruticultura), and Research Institute, Inc. (IRI, New York, United States) (COSTA et al., 1970).

\section{HISTORY}

According to WILLIAMS; SCHUSTER (1970), the first official record concerning the presence of this insect in Brazil was made in 1961 by Prof. Cincinnato Rory Gonçalves, based in the Divisão de Defesa Sanitária Vegetal (Division of Phytosanitary Defense) of the Ministry of Agriculture, Rio de Janeiro. He identified it in a sample of Angola grass from the municipality of Boca da Mata, in the state of Alagoas.

The importance of $A$. graminis increased in Brazil since 1964, and, because this date coincides with the large-scale distribution of pangola grass by farmers, it can be inferred that the mealybug spread in Brazil with pangola grass and woolly finger grass (NUTI, 1969).

The productivity of grasses is greatly affected by intense attacks of the pest. SCHUSTER (1967) related that grazing capacity in the United States was reduced approximately $30 \%$ after the decade of 1940 , this date coinciding with the appearance of the mealybug in that country. In Brazil, in surveys conducted by the Centro de Nutrição Animal de Nova Odessa (Instituto de Zootecnia), in 1969, a decrease on the order of 20 to $38 \%$ was observed when the mean infestation of the mealybug was 11 to 15 insects per tiller (NUTI, 1969).

After the pest was noticed, various insecticides were studied for control of the mealybug. In Australia, CHADA; WOOD (1960) did not obtain promising results. In Brazil, various studies were conducted, and it was concluded that insecticides did not impede reinfestation of the grasses with mealybugs and that chemical control was very costly (CALZA et al., 1969; SUPLICY FILHO et al., 1969; MARICONI, 1976; GALLO et al., 2002).
Based on this situation, biological control utilizing $N$. sangwani was the practice that was most adequate to combat the pest, in view of promising results obtained in India, Africa and the United States.

The introduction of the parasitoid in Brazil occurred in 1967, from specimens from the Center of Research and Extension of the Rio Grande Valley, Weslaco, Texas, and multiplied at the Instituto de Pesquisas e Experimentaçáo Agropecuárias do Leste (IPEAL), in Cruz das Almas (Bahia), where the dissemination of the parasitoid in the country started (WILLIAMS; SCHUSTER, 1970; COSTA et al., 1970).

In São Paulo, the Centro de Nutrição Animal e Pastagens de Nova Odessa received from IPEAL the first colonies of the parasitoids in 1968, and obtained only five specimens, which were multiplied in the laboratory (NUTI, 1969). In this same year, it was introduced in the state of Pernambuco (ARRUDA, 1971).

From 1974, the Instituto Biológico, through its Laboratório de Controle Biológico, headquartered in Campinas, SP, began to multiply and supply $N$. sangwani, with the first colony of wasps sent, in the same year, to the state of Minas Gerais (BATISTA FILHO, 1987). At the end of the decade of 1980, with the substitution of susceptible grasses by other ones which were resistant and easy to manage, there was a reduction in requests for $N$. sangwani. Nevertheless, the Laboratório de Controle Biológico continues to inform interested farmers about the production of this parasitoid.

\section{THE RHODES GRASS MEALYBUG ANTONINA GRAMINIS}

\section{Geographic distribution}

Diverse factors influence the geographic distribution of the mealybugs, especially the host plants of the insect, associated with temperature and humidity, acting in a positive or negative manner on the organism. According to CCHADA et al. (1950), A. graminis is widely distributed in all faunistic regions of the globe, mainly in tropical and subtropical regions, with greatest frequency in areas between the 32nd parallels. In Central and South America, it has been reported in Cuba, Mexico, Puerto Rico, Colombia, El Salvador, Guatemala, Venezuela and Brazil.

\section{Hosts}

Antonina graminis feeds almost exclusively on plants of the family of grasses (Poaceae) (FONSECA, 1967; WILLIAMS; SCHUSTER, 1970). Among the species attacked most in 
Brazil, most notable are pangola, woolly finger, Angola, molasses grass, Natal grass, Bermuda grass, Carib, Rhodes grass, St. Augustine grass, Johnson grass (FONSECA, 1967; BATISTA FILHO; GABRIEL, 1985; WILLIAMS; SCHUSTER, 1970). In contrast, grasses less susceptible are Napier, Guinea, and signal grass, while jaragua grass is considered immune from attacks by the pest (WILLIAMS; SCHUSTER, 1970).

\section{Description and biology}

In the adult stage, the body of the mealybug has an oval form, with a brownish color, sometimes very dark or purplish. It measures approximately $3.0 \mathrm{~mm}$ long by $1.5 \mathrm{~mm}$ wide at the widest region of the body, which is encased in a white substance secreted by the insect in a form similar to a bag with the consistency and appearance of felt (Fig. 1). At the anterior and posterior extremities of the body, in the cephalic and anal regions, protruding from the body, there are white filaments with feeding and excretory functions, respectively (CHADA; WOOD, 1960). Liquid substances excreted through these tubes spreads across the surface of plants and serve for the development of sooty mold (FONSECA, 1967).

Antonina graminis is an ovoviviparous species, that is, the females give birth to small nymphs; and reproduction is via thelytokous parthenogenesis, that is, unfertilized females produce other females. It has three nymphal instars, with mobility restricted to a few days during the first instar (Fig. 2). In subsequent stages, the mealybug has a sedentary life. The total development cycle of the insect is 60 to 70 days, with five generations per year. The range of temperature between 29 and $32^{\circ} \mathrm{C}\left(85\right.$ a $\left.90^{\circ} \mathrm{F}\right)$ is considered optimal (CHADA; WOOD, 1960).

\section{Damage}

The presence of the mealybug in any grass becomes evident because of the white color of its secretion. The infestation is most intense in the region of the base (Fig. 1). Under conditions

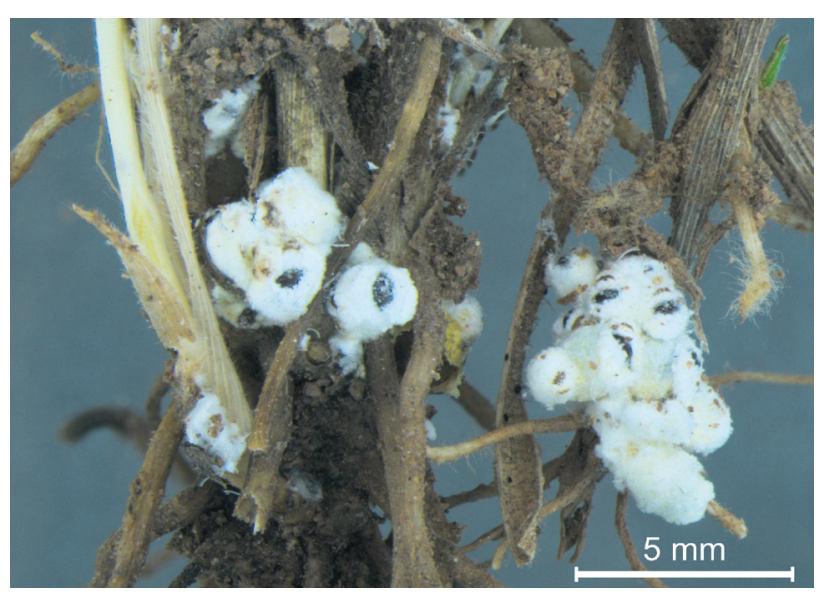

Figure 1. Rhodes grass mealybugs on the base of Natal grass. of high populations, the pest migrates to the aerial parts of plants and under leaf sheaths. They can also invade the upper portions of roots (CHADA; WOOD, 1960).

The insect sucks the sap of plants, resulting in weakening and a loss of their capacity for regrowth; under severe infestations, the plants dry and die, a symptom known as "frost" (CHADA; WOOD, 1960; FONSECA, 1967; GALLO et al., 2002). Because of the irregular distribution of the pest, symptoms of attack are noticed as dry spots that appear gradually in the pasture (GALLO et al., 2002).

In the United States, SCHUSTER (1967), working with diverse forage plants, concluded that the loss in production due to the attack by the mealybug in Rhodes grass and Bermuda grass was 18.0 and $59.1 \%$, respectively.

In Brazil, surveys at the Centro de Nutrição Animal e Pastagens de Nova Odessa, of Angola grass, indicated that there was a decrease in grazing capacity on the order of 20 to $38 \%$, when the infestation mean was between 11 and 15 mealybugs per tiller (NUTI, 1969).

The natural dispersion of this mealybug is very slow. Tools and equipment used in cultural treatments, animals, and wind are the principal agents responsible for its dissemination, as well as grass sod and cuttings transferred from infested areas to non-infested areas (CHADA; WOOD, 1960; FONSECA, 1967). GLICK (1939) found that air currents can carry wingless insects to altitudes of up to 1,650 meters, demonstrating

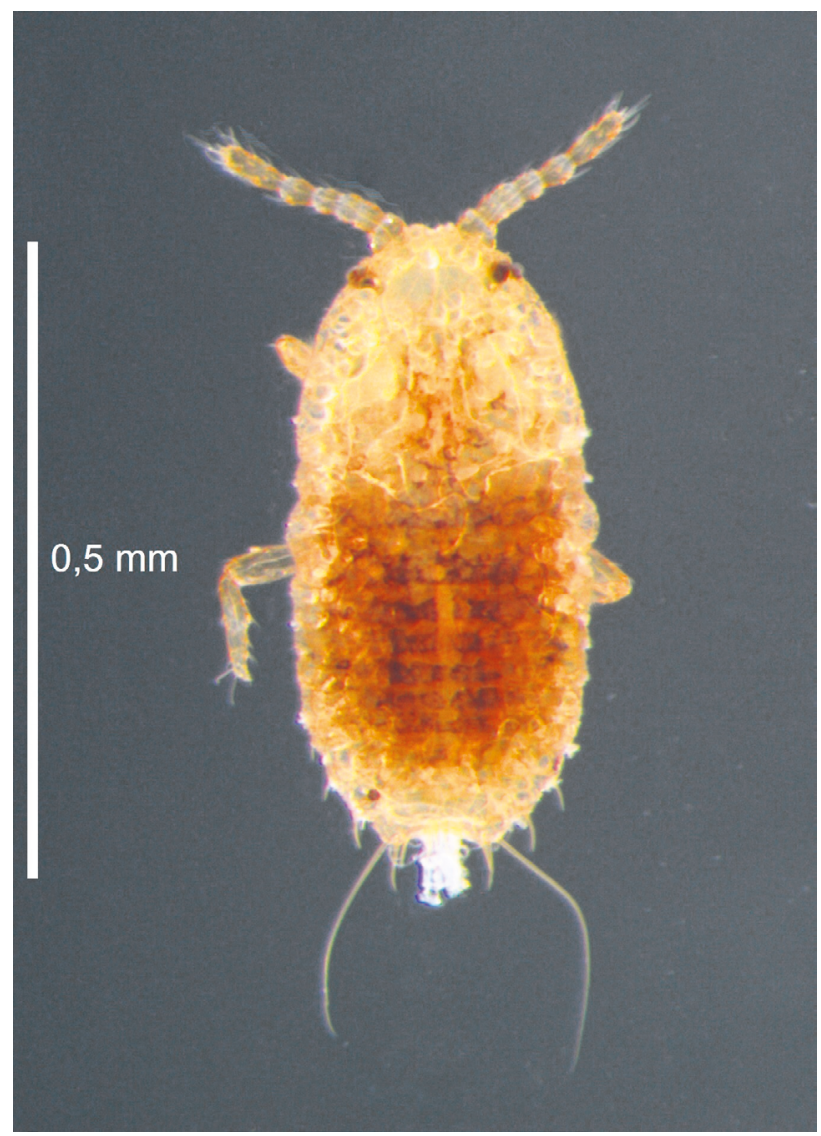

Figure 2. Nymph of Antonina graminis. 
the facility with which this mealybug can be disseminated in regions with strong and constant winds.

\section{THE PARASITOID NEODUSMETIA SANGWANI}

\section{Description and biology}

Neodusmetia sangwani was described as Dusmetia sangwani, from specimens collected in India parasitizing $A$. graminis (SUBBA RAO, 1957). KERRICH (1964) transferred the species to the genus Neodusmetia. The adult is a wasp that measures about $1 \mathrm{~mm}$ long and lives only 12-48 hours (SCHUSTER, 1965). The females are wingless, with the head and thorax orange-brown, with the thorax lighter in color, and the abdomen dark brown; its antennae are brown, with the extremities white (Fig. 3). The males are winged with a body completely dark brown, and with antennae and legs slightly lighter in color (Fig. 4) (NOYES, 2000).

The biology of $N$. sangwani was studied in detail by SCHUSTER (1965) and SANTOS (1976). The cycle of the wasp begins with a female of the parasitoid laying its eggs in the interior of the body of the mealybug, preferably those of the third instar, a process that lasts 2 to 5 seconds. From the eggs, hatch larvae of the parasitoid that, while feeding on the mealybug, impede its production of nymphs, culminating with its death. Its development is completed in 17 to 20 days at $30^{\circ} \mathrm{C}$ and 47 to 56 days at $20^{\circ} \mathrm{C}$. In mean numbers, each wasp parasitizes 6.3 mealybugs, producing 35.3 descendants,

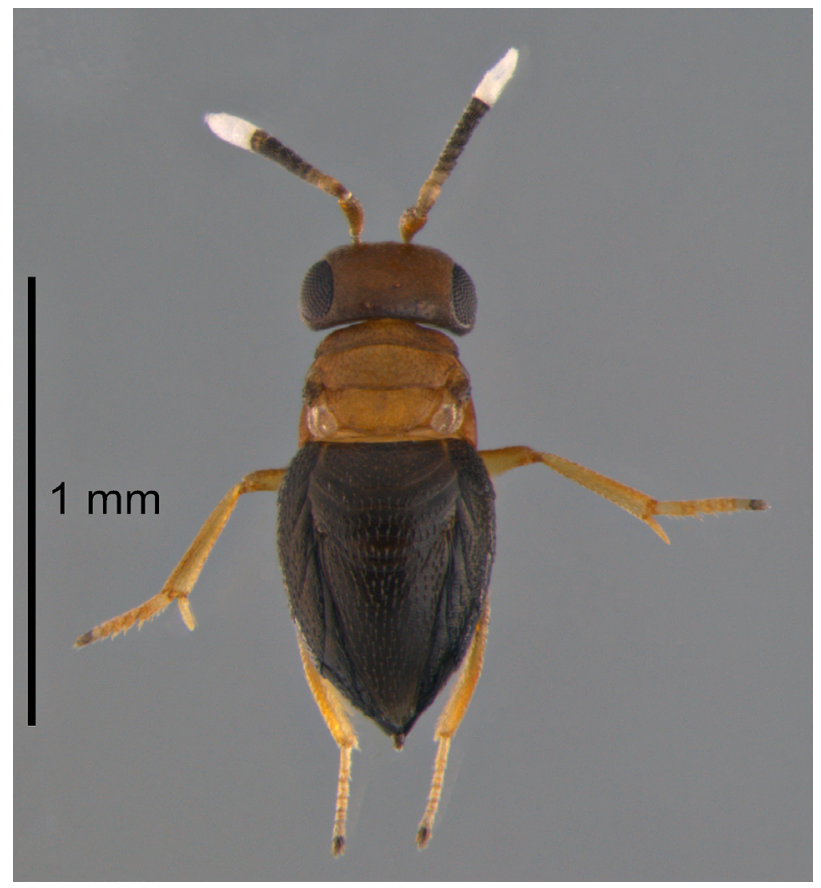

Figure 3. Female of Neodusmetia sangwani. or 5.5 to 6.2 per mealybug. The females are more abundant than males, in a proportion of 4.1 to $6.7: 1$.

According to NUTI (1969), the wasp produces seven generations more than the mealybug annually, in conditions of Nova Odessa, SP. Its natural dispersion capacity is estimated to be only 800 meters per year (SCHUSTER; BOLING, 1971).

\section{Multiplication and release}

Ahead are presented procedures recommended for multiplication and field release of the parasitoid based on COSTA et al. (1970) (Fig. 5). The first lot of wasps can be obtained from the Laboratório de Controle Biológico of the Instituto Biológico, based in Campinas, or from a region where their occurrence is already known. This initial lot will be multiplied by the producer, to release on his property. Rearing is done using grass infested with mealybugs, maintained in transparent plastic bags of 3 to 4 liters, and without holes, to prevent the escape of the insects (Fig. 6).

After obtaining the first generation of parasitoids on the property, they will be released in the field. Because the wasps live for only a very short time as adults, a maximum of 48 hours, they should be placed in contact with the mealybugs as rapidly as possible. It will be necessary an entomological aspirator (Fig. 7) to facilitate the collection of the wasps, and for their transfer to plastic bags containing mealybugs to be used for their multiplication. This apparatus can be constructed with tubes of glass or plastic and metal, a rubber or cork stopper, and flexible rubber or plastic tubing (SCHAUFF, 2016).

To rapidly achieve control, a release in the field of four or five colonies of the parasitoid per hectare is recommended. 
To form the colony, place 30 wasps in a plastic bag containing 120 mealybugs. Consider one mealybug per tiller and wait for the appearance of the first generation of the wasps.

In order to know whether the scales are parasitized or not, put the infested grass in a transparent plastic bag and observe daily. The parasitoid can be recognized by being a brown, wingless insect near $1 \mathrm{~mm}$ long, and it jumps when disturbed. In the same sample other parasitoid species can occur, but they are winged; also, first-instar nymphs can be present, but they are smaller ( $0.5 \mathrm{~mm}$ long) and do not jump.

Thus, the procedures for multiplication of the parasitoid are:

1. Collect grass infested with the mealybugs and cut off its leaves and roots, leaving the region of the base with 4 to $7 \mathrm{~cm}$ of stems, being careful to avoid damaging the

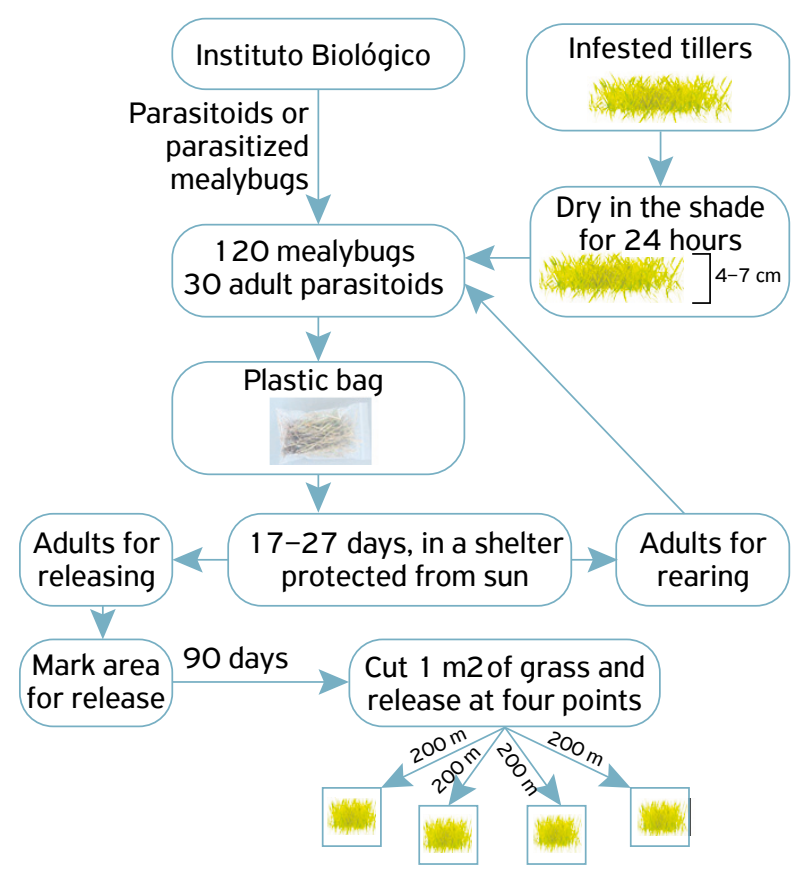

Figure 5. Diagram for multiplication and release of Neodusmetia sangwani.

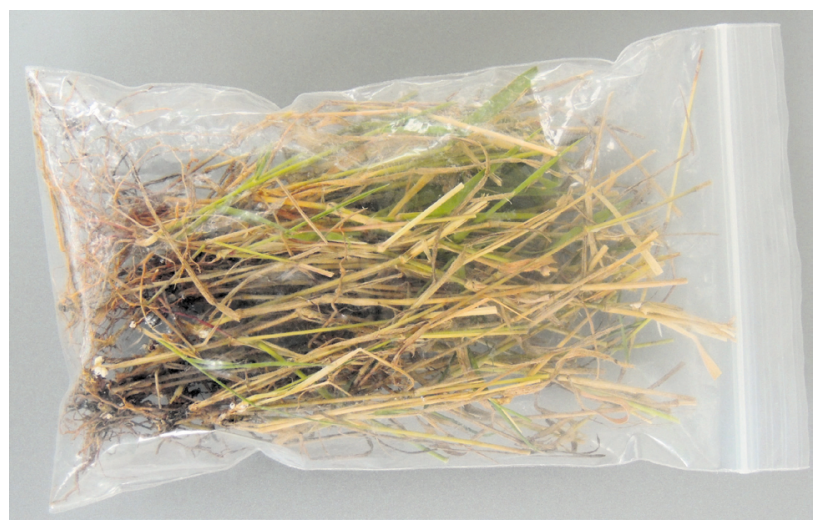

Figure 6. Colony of mealybugs maintained in a plastic bag containing Neodusmetia sangwani. mealybugs. If the grass is wet or very humid, allow it to dry in the shade for two days;

2. Place the cut grass in a plastic bag or other closed container;

3. Collect with the entomological aspirator nearly 30 wasps from the tillers that arrive by mail, put them directly in the plastic bag with the recently collected mealybugs and close it;

4. Store the plastic bag in an enclosed area which will not receive direct sunlight. If possible, the material should be maintained at $28^{\circ} \mathrm{C}$.

A variation of this method is to place all of the tillers that arrive in the mail directly in the plastic bag with new tillers. With this method, the wasps already are in contact with the mealybugs as soon as they emerge as adults and promptly initiate their reproduction, saving the producer the task of collecting the adult wasps, eliminating the use of the aspirator and the risk of losing them if the collection is not made in time. The disadvantage of this method is the lack of control of the number of wasps used in the process.

The first generation of wasps should emerge after a period of 17 to 27 days, depending on the temperature. The hotter it is, the faster is the cycle of reproduction. Therefore, the plastic bags should be inspected three times per day, from the 17th day. When emergence of the first adults is observed, the producer should proceed to their release in the field.

Since the females of these parasitoids are wingless, it is necessary to help these insects in their dispersion in the pasture, distributing the emerged adults in the areas infested by

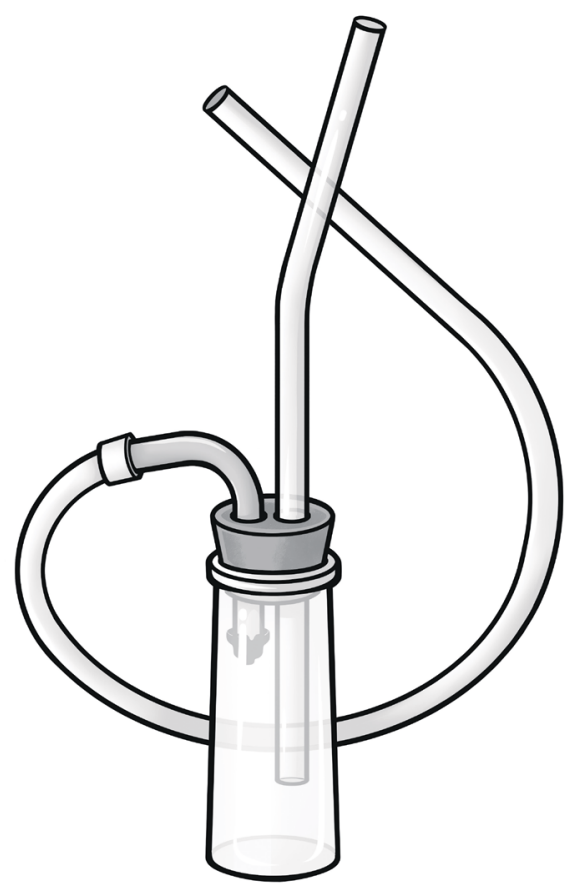

Figure 7. Entomological aspirator. Illustration based on GALLO et al., 2002. 
the mealybug. This distribution in the field should always be done late in the afternoon, when the temperature is milder. The procedure is as follows:

1. Choose an area heavily attacked, showing symptoms of "frost", and mark it with a stake;

2. Release a half of the parasitoids of a colony in an area of approximately $1 \mathrm{~m}^{2}$. The other half should be placed in another local with similar attack. To avoid trampling by cattle, this first area where the wasps were released can be fenced. If the producer thinks it is better, he can take the parasitized mealybugs directly to the pasture when the wasps begin to appear, and leave them there, preferably in an area protected from the sun. The wasps will procure the mealybugs as soon as they emerge as adults;

3. After 90 days, collect all of the grass from the area of $1 \mathrm{~m}^{2}$ around the stake, cutting the grass very close to the ground in order to obtain the greatest number of parasitized mealybugs possible;

4. Divide this cut material in four parts and distribute it in four areas of the pasture about $200 \mathrm{~m}$ from each other, and that also have symptoms of attack of the pest. In each new point of release, spread the tillers in an area of $1 \mathrm{~m}^{2}$;

5. Mark these locations with stakes and after 90 more days repeat the procedure in new areas (Fig. 8).

Observation: Producers should not burn the pasture nor use insecticides in the areas where the wasps were released.

With this method, biological control of $A$. graminis will be established and the population of the pest will be maintained at a level that does not cause damage.

The wasp Neodusmetia is the parasitoid recognized to be most efficient to control the Rhodes grass mealybug. However, other species of parasitoids can attack this pest, including Anagyrus ananatis Gahan, Anagyrus antoninae Timberlake, Anagyrus brevistigma De Santis and Anagyrus pseudococci (Girault) (Hymenoptera: Encyrtidae) (GABRIEL, 1982;

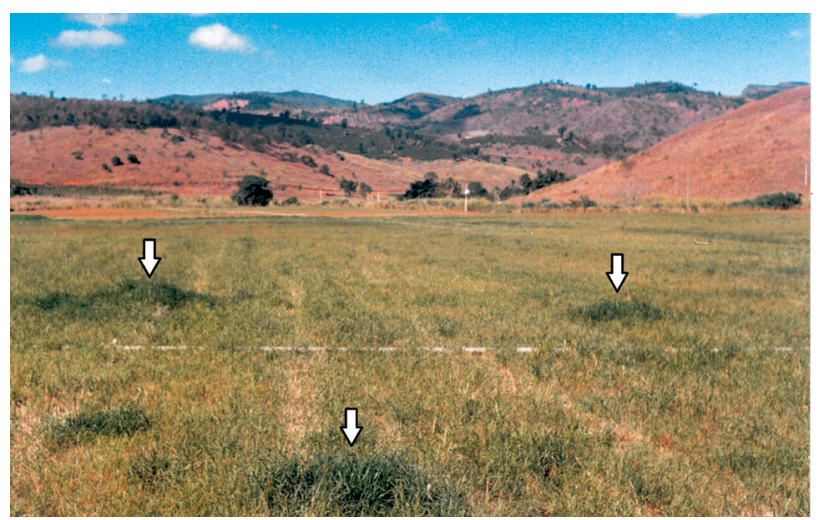

Figure 8. Area of Rhodes grass infested by $A$. graminis, showing the locations of release of the parasitoid $N$. sangwani (darker green areas) in Santa Teresa, ES. 1988. Photo: Fernando Corteletti. 1983a; 1983b; GABRIEL et al., 1982). In the southeastern United States, CHANTOS et al. (2009) found that another parasitoid species, Acerophagus sp. (Hymenoptera: Encyrtidae), probably native to the United States, was as abundant as the introduced $N$. sangwani.

\section{Efficiency of control in Brazil}

According to CALZA et al. (1969), SUPLICY FILHO et al. (1969), MARICONI (1976) and GALLO et al. (2002), chemical control of the Rhodes grass mealybug is economically unviable because of the high cost and inefficiency of the products, which are unable to reach the pest, as well as problems of contamination of the environment, cattle, and humans. The most viable form to control this pest is the biological method, through the release of the parasitoid N. sangwani.

NUTI (1969) reports the perfect adaptation of the parasitoid to climatic conditions of Nova Odessa, SP, obtaining a percentage of attack of the wasp varying from 75.9 to $85.1 \%$, at a mean temperature of $28^{\circ} \mathrm{C}$.

BATISTA FILHO; SILVA (1988a; 1988b) found, in Campinas, $35 \%$ of mealybugs parasitized. They observed that the temperature means of 25 to $27^{\circ} \mathrm{C}$ increased the level of total parasitism and multiplication of $N$. Sangwani and that the relative humidity of the air did not influence, in a limiting form, the parasitism.

Under conditions of Fortaleza, CE, SANTOS (1976) observed that the population of the wasp reached equilibrium with the mealybug five months after the release of the parasitoid in the field. In São Paulo state, GABRIEL (1983b) related that there was recovery of $N$. sangwani in pangola grass in Araçatuba, 10 years after the first release, and in Piracicaba after eight years, demonstrating that the parasitoid has a perfect adaptation to the climatic conditions, being efficient and permanent in the control of $A$. graminis. However, if it is necessary to apply insecticides for control of other pests, such as leafhoppers, this can cause disequilibrium by the elimination of $N$. sangwani in the area, resulting in elevated infestations by $A$. graminis.

There are no studies on the status of the biological of $A$. graminis in Brazil since the early 1980s, perhaps because of the use of resistant grasses. In the United States, due to the lack of information about the status of the biological control of A. graminis in the field, CHANTOS et al. (2009) conducted a survey in the southeastern states. They observed that $N$. sangwani was not as common as expected, having an uneven geographic distribution, with low percentage of parasitism in most of the sites. According to the authors, one of the possible reasons for these results would be that the parasitoid has not dispersed widely since its introduction. In this case, releasing $N$. sangwani in regions where it does not occur might help in the control of A. graminis. Also, the red imported fire 
ant, Solenopsis invicta Buren (Hymenoptera: Formicidae), might be interfering with biological control, since this invasive ant benefits from the honeydew produced by $A$. graminis (HELMS; VINSON, 2002). However, this interference still needs clarification.

\section{FINAL CONSIDERATIONS}

Neodusmetia sangwani possesses two attributes that could disqualify its use in programs of biological control, which are its short longevity and the fact that the females are wingless, slowing their dispersion. However, it has a series of characteristics like ease of handling, high rate of parasitism, ease of adaptation to environmental conditions, of transport and release in the field, and greater number of generations annually than $A$. graminis, showing significant speed of growth of the population compared to the target insect. In addition to these attributes, it can be multiplied and released in the field by the rural producer himself. For these reasons, biological control of Antonina graminis by Neodusmetia sangwani is an example of the success of classical biological control in Brazil and in the world.

\section{ACKNOWLEDGMENTS}

Acknowledgments to Fernando Corteletti, Santa Teresa, Espírito Santo, Brazil, for the picture of the area where $N$. sangwani had been released for the control of $A$. graminis; to Mário César Coelho Kokubu, Instituto Biológico, São Paulo, Brazil, for the help with the illustrations of $N$. sangwani rearing; Sandro Hojo, Guarulhos, São Paulo, Brazil, for the help with the illustration of the entomological aspirator.

\section{REFERENCES}

ARRUDA, G.P. Contribuição ao estudo da cochonilha do capim Antonina graminis (Maskell, 1897) (Homoptera: Pseudococcidae)e seu controle biológico no Pernambuco. 80f. Dissertation (Mestrado) - Universidade de São Paulo, Piracicaba, 1971.

BATISTA FILHO, A. Controle biológico da cochonilha dos capins. O Biológico, São Paulo, v.53, p.63-67, 1987.

BATISTA FILHO, A.; GABRIEL, D. Controle Biológico da cochonilha Antonina graminis (Maskell) pelo inimigo natural Neodusmetia sangwani (Rao). O Biológico, São Paulo, v.51, p.167-168, 1985.

BATISTA FILHO, A.; SILVA, E.M. Influência da época do ano no parasitismo de Neodusmetia sangwani (RAO, 1957) sobre a cochonilha Antonina graminis Maskell, 1897. O Biológico, São Paulo, v.54, p.35-37, 1988a.

BATISTA FILHO, A.; SILVA, E.M. Observações sobre a cochonilha Antonina graminis. Pesquisa Agropecuária Brasileira, Brasília, v.23, p.329-331, 1988b.

CALZA, R.; SUPLICY FILHO, N.; NUTTI, P. Primeiros resultados do controle químico da Antonina graminis (Maskell) praga do capim pangola (Digitaria pentzii), com inseticidas granulados. $O$ Biológico, São Paulo, v.35, p.223-226, 1969.

CHADA, H.L.; WOOD, E.A., Jr. Biology and control of the Rhodesgrass scale. Washington, D.C.: USDA, 1960. 21 p. (Technical Bulletin, 1221).

CHADA, H.L.; WOOD, E.A., Jr.; RIHERD, P.T. Distribution and host plants of the Rhodes-grass scale in the United States in 1950. Washington, D.C.: USDA Bureau of Entomology and Plant Quarantine, Insect Pest Survey, 1950. 5p. (Special Supplement, 5).
CHANTOS, J.M.; VINSON, S., HELMS, K.R. Distribution and abundance of parasites of the Rhodes-grass mealybug, Antonina graminis: reassessment of a classic example of biological control in the southeastern United States. Journal of Insect Science, Tucson, v.9, n. 1, p.1-6, 2009. doi: https://doi.org/10.1673/031.009.4801

COSTA, J.M.; WILLIAMS, R.N.; SCHUSTER, M.F. Cochonilha dos capins, Antonina graminis, no Brasil. Il. Introdução de Neodusmetia sangwani, inimigo natural da cochonilha, Pesquisa Agropecuária Brasileira, Rio de Janeiro, v.5, p.339-343, 1970.

FONSECA, J.P. Uma cochonilha de capim recentemente introduzida no Brasil. O Biológico, São Paulo, v.33, p.57-61, 1967.

GABRIEL, D. Levantamento da ocorrência da cochonilha Antonina graminis (Maskell, 1897) (Homoptera: Pseudococcidae) e de seus parasitos, em áreas de pastagens do Estado de São Paulo. I - Municípios de Piracicaba e São Pedro. O Biológico, São Paulo, v.48, p.195-200, 1982.

. Levantamento da ocorrência da cochonilha Antonina graminis (Maskell, 1897) (Homoptera: Pseudococcidae) e de seus parasitos, em áreas de pastagens do estado de São Paulo. II - Municípios de Araçatuba, Coroados, Capela do Alto, Araçoiaba da Serra, Votorantim, Salto de Pirapora, Cravinhos, Pedregulho, Restinga, Batatais e Assis. O Biológico, São Paulo, v.49, p.5364, 1983a.

. Levantamento da ocorrência da cochonilha Antonina graminis (Maskell, 1897) (Homoptera: Pseudococcidae) e de seus parasitos, em áreas de pastagens do Estado de São Paulo. III-Municípios de Martinópolis, Caiabú, Regente Feijó, Indiana, Onda Verde, Bady Bassitt Nova Granada. O Biológico, São Paulo, v.49, p.207-128, 1983b. 
GABRIEL, D.; DEL VECCHIO, M.C.; MUNIZ, J.P.; RAMIRO, Z.A. Ocorrência de Anagyrus pseudococci (Girault, 1915) (Hymenoptera: Encyrtidae), parasitando a cochonilha Antonina graminis (Maskell, 1897) (Homoptera: Pseudococcidae) em Caconde, São Paulo. O Biológico, São Paulo, v.48, p.157-159, 1982.

GALLO, D.; NAKANO, O.; SILVEIRA NETO, S.; CARVALHO, R.P.L;; BAPTISTA, G.C.; BERTI FILHO, E.; PARRA, J.R.P.; ZUCCHI, R.A.; ALVES, S.B.; VENDRAMIN, J.D.; MARCHINI, L.C.; LOPES, J.R.S.; OMOTO, C. Entomologia Agrícola. Piracicaba: FEALQ, 2002. 920p.

GLICK, P.A. The distribution of the insects, spiders and mites in the air. Washington, D.C.: USDA, 1939. 150p. (Technical Bulletin, 673).

HELMS, K.R.; VINSON, S.B. Widespread association of the invasive ant Solenopsis invicta with an invasive mealybug. Ecology, Brooklyn, v.83, p.2425-2438, 2002. doi: https:// doi.org/10.1890/0012-9658(2002)083[2425:WAOTIA ]2.0.CO;2

KERRICH, G.J. On the European species of Dusmetia Mercet and a new Oriental genus (Hym.; Chalcidoidea, Encyrtidae). Entomophaga, Paris, v.9, n. 1, p.75-79, 1964.

MARICONI, F.A.M. Inseticidas e seu emprego no combate às pragas. São Paulo: Nobel, 1976. Tomo II. 466p.

NOYES, J.S. Encyrtidae of Costa Rica (Hymenoptera: Chalcidoidea) 1: The subfamily Tetracneminae, parasitoids of mealybugs (Homoptera: Pseudococcidae). Gainesville, 2000. (Memoirs of the American Entomological Institute, 62).

NUTI, P. Controle biológico da cochonilha - Antonina graminis (Maskell) pelo inimigo natural Neodusmetia sangwani (RAO). Boletim de Indústria Animal, Nova Odessa, v.25, p.255-261, 1969.
SANTOS, J.H.R. Controle Biológico da Antonina graminis (Maskell, 1897) pela Neodusmetia sangwani (Rao, 1957) em Fortaleza no Estado do Ceará, Brasil. Anais da Sociedade Entomológica do Brasil, Londrina, v.5, p.18-28, 1976.

SCHAUFF, M.E. Collecting and preserving insects and mites: techniques and tools. Washington, D.C.: ARS/USDA. 68p. Available from: <http://www.ars.usda.gov/SP2UserFiles/ad_hoc/1275 4100 CollectingandPreservinglnsectsandMites/collpres.pdf $>$. Accessed on: May 23, 2016.

SCHUSTER, M.F. Response of Forage Grasses to rhodesgrass Scale. Journal of Range Management, Denver, v.20, p.307-309, 1967.

Studies on the biology of Dusmetia sangwani (Hymenoptera: Encyrtidae). Annals of the Entomological Society of America, College Park, v.58, p.272-275, 1965.

SCHUSTER, M.F.; BOLING, J.C. Biological control of rhodesgrass scale in Texas by Neodusmetia sangwani (Rao): effectiveness and colonization studies. Bulletin / Texas Agricultural Experiment Station, College Station, n.1 104, p.5-15, 1971.

SUBBA RAO, B.R. Some new species of Indian Hymenoptera. Proceedings of the Indian Academy of Sciences, Section B, Bangalore, v.46, p.376-370, 1957.

SUPLICY FILHO, N.; NUTTI, P.; CALZA, R. Ensaio para o controle da Antonina graminis (Maskell), praga do capim pangola (Digitaria pentzii) com inseticidas sistêmicos granulados. O Biológico, São Paulo, v.35, p.22-24, 1969.

WILLIAMS, R.N.; SCHUSTER, M.F. Cochonilha dos capins (Antonina graminis) no Brasil. I- Distribuição e plantas hospedeiras. Pesquisa Agropecuária Brasileira, Brasília, v.5, p.215-218, 1970. 